\title{
Zygmunt Zieliński
}

Lublin

\section{Okupacyjna saga rodzinna*}

Nie jest łatwo recenzentowi względnie komuś, kto chciałby się pokusić o komentarz, refleksję, nie mówiąc o ambitniejszej analizie, wziąć na warsztat wspomnienia, zapiski, dzienniki czy nawet relacje o wydarzeniach osobiście nieprzeżywanych przez piszącego, a tylko przekazanych z trzeciej ręki. Pierwsza trudność to brak punktu zaczepienia dla uwag krytycznych. Zawsze tamę stanowi naturalny w takich utworach subiektywizm - nie tylko ocen, ale także widzenia świata, ludzi i zdarzeń. Konfrontacje z równoległymi utworami tego typu, także w sensie chronologicznym i miejsca zdarzeń, nic nie dają, gdyż si duo faciunt idem, non est idem - dwa oglądy tego samego zdarzenia mogą być i bywają przeważnie różne. Nikłe możliwości weryfikacji przekazu dają także inne źródła, nawet te z natury obiektywne, a więc dokumenty. Także przed nimi bronią się pamiętniki, wspomnienia, dzienniki. Jest to mankament, a zarazem cenna cecha wyróżniająca te dzieła jako owoc percepcji świata w określonych okolicznościach.

Na wstępie wypada skomentować tytuł Dziennika, gdzie mowa o wojnie i okupacji. Ostatni zapis pochodzi z 10 IX 1945 r. Autor Dziennika przyjmuje ten dzień jako zakończenie drugiej wojny światowej po kapitulacji Japonii. Ta drobna nieścisłość jest zrozumiała, gdyż w ówczesnych warunkach komunikacji medialnej faktyczny dzień kapitulacji - 2 września - nie był odległy od daty zawartej w Dzienniku. Inna sprawa związana z tytułem dzieła może rodzić pewne spekulacje, choć treścią zapisu bynajmniej nie usprawiedliwione. $Z$ tytułu wynika, iż okupacja trwała jeszcze w 1945 r. Wydaje się jednak, że autorowi nie towarzyszyła taka myśl, kiedy nadawał Dziennikowi ramy chronologiczne. Na temat dominacji sowieckiej wprost nie pisze, choć można się jej domyślać z pewnych zapisów. Po wyparciu Niemców z Lublina dotyczą one zresztą niemal wyłącznie problemów bytowych.

Okoliczności towarzyszące powstawaniu Dziennika były szczególnie wyraziste. To była okupacja niemiecka. A następnie niecodzienny okazał się też sam proces rodzenia się dzieła. Autor, znany prawnik, predestynowany był jak mało kto do obserwacji otaczającej go rzeczywistości i przenoszenia ich na papier. Współautorami była czwórka jego dzieci: Maria Kalina, mająca w momencie nastania okupacji piętnaście lat, Józef Leszek, wówczas trzynastoletni chłopiec, Lidia Teresa - licząca dziesięć lat, i Barbara Zofia — osiem lat. Wszystkie one przeżywały okupację w pełni świadomie, a ponieważ na Lubelszczyźnie trwała ona pięć lat, należy wziąć pod uwagę także proces ich dojrzewania, w warunkach okupacyjnych znacznie przyspieszony. To sprawiło, że obserwacje owych młodych ludzi, z pewnością bliższych wydarzeniom dnia powszedniego niż ich ojciec, ogromnie podnoszą wartość przekazywanych treści. Dziennik redagował ojciec, czerpiąc z zapisków dzieci, niekiedy je parafrazując i opatrując własnymi uwagami, a innym razem włączając tekst dzieci in extenso.

Zaznaczyć należy na wstępie, iż Dziennik nie daje całościowego obrazu miasta w czasie okupacji, ale jest mozaiką przekazów powstających na kanwie doświadczeń osób robiących zapiski.

\footnotetext{
* Remigiusz Moszyński, Dziennik 1939-1945. Wojna i okupacja w Lublinie w oczach dorostych i dzie$c i$, opracował i wstępem opatrzył ks. Edward Walewander, Lublin 2014, Towarzystwo Naukowe Katolickiego Uniwersytetu Lubelskiego Jana Pawła II.
} 
Niektóre informacje natury ogólniejszej, np. szczegóły dotyczące operacji na poszczególnych frontach, budzą pewne zastrzeżenia, gdyż autor relacjonuje wydarzenia rozgrywające się w warunkach, których krytyczna ocena przekraczała jego możliwości. Ich obecność w Dzienniku dowodzi tylko skrupulatności Remigiusza Moszyńskiego i każe suponować jego zamysł przekazania źródła dla przyszłych pokoleń. Autor czerpał tę wiedzę z niemieckich komunikatów wojennych, a także — jak na to wskazują niektóre nazwy geograficzne nie do zidentyfikowania — z innych źródeł informacji. Mogła to być prasa podziemna, nasłuchy radiowe lub po prostu bardzo wówczas rozpowszechniona tzw. poczta pantoflowa. Ślady prasy niemieckojęzycznej, a także — lub może przede wszystkim — jedynej w Lublinie wychodzącej gadzinówki są w Dzienniku bardzo wyraźne ${ }^{1}$.

Liczne w Dzienniku informacje o losach toczącej się wojny świadczą niewątpliwie o zrozumiałym zainteresowaniu zarówno sukcesami, jak i klęskami Niemców. Ogólnie należy zaznaczyć, że zwłaszcza częste w Dzienniku zapisy o np. stratach sowieckich czy alianckich należałoby zweryfikować, gdyż niemieckie źródła informacji były pod tym względem nastawione na propagandowe oddziaływanie, w przypadku odbiorcy w kraju okupowanym miały siać i umacniać defetyzm oraz przekonanie o niezwyciężoności III Rzeszy. Z kolei niepowodzenia niemieckie były niejednokrotnie w umiejętny sposób kamuflowane odpowiednią retoryką. O sytuacji na frontach donosiły wyłącznie tzw. Sprawozdania Naczelnego Dowództwa Wehrmachtu (Berichte des Oberkommandos der Wehrmacht) ${ }^{2}$, ewentualnie komentarze Ministerstwa Propagandy, pod koniec wojny często autorstwa samego Josepha Goebbelsa. Do jakiego stopnia opinia publiczna była manipulowana przez te doniesienia OKW, niech świadczy zapis z 16 I 1943 r. na temat sytuacji w Stalingradzie. W brzmieniu dosłownym przedstawia się to następująco: Im Raum von Stalingrad schlugen unsere Truppen die dort seit Wochen in heldenmutigem Abwehrkampf gegen den von allen Seiten angreifenden Feind stehen, starke Angriffe ab. (Na terenie Stalingradu wojska nasze toczące od tygodni bohaterską walkę obronną przeciwko ze wszech stron nacierającemu wrogowi odparły silne ataki). Kapitulację 6 Armii feldmarszałka Paulusa podano do wiadomości dopiero po trzech dniach po fakcie, 3 II 1943 r.

Zapis w Dzienniku bardzo często przekazuje pogłoskę trudną w tamtych warunkach do sprawdzenia, a zresztą autor i współdziałające $\mathrm{z}$ nim dzieci nawet nie mieli takiego zamiaru, gdyż ich celem było pokazanie życia okupacyjnego bez retuszu. Na szczęście w omawianym tu tomie aparat, jakim tekst został opatrzony, pozwala współczesnemu czytelnikowi, nawet temu zgoła niezorientowanemu w warunkach okupacyjnych, uzyskać zarówno koloryt takiego życia, jak i uściślone na jego temat wiadomości. Nie zawsze było to możliwe w przypadku miejscowości, gdzie toczyły się walki, zwłaszcza w schyłkowym okresie wojny, gdyż ich nazwy były albo zniekształcone, albo też o nikłym znaczeniu strategicznym.

Głównym narratorem jest w Dzienniku Remigiusz Moszyński, toteż zasadnicze treści o ogólnym znaczeniu są jego dziełem, natomiast niezwykle szczegółowy obraz miasta w czasie okupacji, łącznie ze skądinąd mniej ważnymi zmianami, jakie ona przyniosła i poznawczo ciekawym obrazem np. handlu, cen, zaopatrzenia to przede wszystkim dzieło trojga dzieci Moszyńskiego. Wstawki ich tekstów, głównie Leszka, ale nie tylko, bo i Kaliny (przede wszystkim), i Barbary, wnoszą więcej niż rutynowe odnotowania będące główną osnową Dziennika.

Dziennik ma wiele warstw tematycznych i problemowych i każda z nich wymaga innego postrzegania i oceny. Najpierw ogólnie trzeba stwierdzić, że stanowi on bardzo cenne źródło

\footnotetext{
${ }^{1}$ W Lublinie wychodził w czasie okupacji „Nowy Głos Lubelski” jako gadzinówka polskojęzyczna.

${ }^{2}$ Są one dostępne obecnie w publikacji: Die Berichte des Oberkommandos der Wehrmacht 1939-1945, t. 5, München 2004.
} 
dla dziejów Lublina w czasie wojny i okupacji. Jego autorem jest prawnik znający doskonale środowisko i przez cały czas okupacji przebywający w mieście. Poza tym zapiski robiły jego dzieci dorastające w czasie okupacji. Całą rodzinę cechuje wielka wrażliwość na zjawiska społeczne, patriotyczne, religijne, co znajduje wyraz w obserwacji otoczenia i potrzebie uwieczniania doznanych wrażeń.

Z kolei, przechodząc do tematów szczegółowych, zauważyć należy kreślone bardzo plastyczne charakterystyki Niemców i ich odnoszenia się do Polaków, a w wymiarze szerszym świadomego zagospodarowywania zdobytego terenu. Nosi ono znamiona typowe dla propagandy III Rzeszy, która zdobyte na wschodzie, a więc także w Polsce, tereny określała jako niemiecki Lebensraum i przygotowywała je do planowanego osadnictwa niemieckiego, co w pewnych regionach (Zamojszczyzna) już wprowadzano w życie. Te próby udowodnienia za pomocą faktów dokonanych praniemieckiego pochodzenia (urdeutsche Herkunft) wielu miast polskich — obok Krakowa także Lublin był tak postrzegany — zostały doskonale uchwycone w opisach zmian wprowadzanych w ich wyglądzie, np. oznaczenie wielu ulic niemieckimi nazwami, co wiązało się ze sporządzeniem niemieckiej mapy miasta, z zasiedlaniem niektórych ulic wyłącznie niemieckimi mieszkańcami, co powodowało wysiedlenie Polaków. Wypadki takie po prostu odnotowywano, nie dokonując jakichś ad hoc sporządzanych analiz, ale rejestrując zdarzenia ściśle umiejscowione chronologicznie. Jawiący się tu obraz Niemca nie ma charakteru stereotypu. Jest tak właśnie dlatego, że Dziennik przede wszystkim rejestruje, w niewielu tylko przypadkach oceniając, dostrzeżone zjawiska. Może ta powściągliwość sprawia niekiedy wrażenie w owych czasach niezrozumiałego dystansu do opisanych wydarzeń. Wydaje się jednak, że autorowi czy autorom przyświecała chęć wykazania daleko idącego obiektywizmu. Dlatego nie ukrywa się pewnych, odosobnionych wprawdzie, ale zdarzających się działaniach niektórych Niemców na korzyść Polaków lub zdradzających ludzkie do nich podejście. Z drugiej strony bardzo wyraziście ukazano całą machinę śmierci — nie tylko na terenie Majdanka - w której Niemcy uczestniczyli niemal rutynowo. Dziennik wszakże, co należy podkreślić, nie śledzi systematycznie eksterminacyjnych poczynań Niemców. One pojawiają się niejako okazyjnie.

Zapiski o postawach ludności polskiej wskazują na wielkie rozwarstwienie, gdy chodzi o postawy etyczne, patriotyzm i zmysł społeczny. Dziennik doskonale, bez emocji, kreśli wiele sylwetek ludzkich i z pewnością burzy pewne mity. Mimo opisów zachowań poszczególnych spotkanych przez autorów osób, gdzie w pewnych proporcjach jawią się ludzie wielkiego formatu obok wyraźnego marginesu lub po prostu takich, którzy pragnęli przeżyć za wszelką cenę i to kształtowało ich zasady etyczne, brak jednak jakiejś przeciętnej, która ukazałaby społeczny wymiar postaw. Wszystko jednak zależało od konkretnych przeżyć autorów. Tylko one dostarczały materiału do odnotowań.

Wiele do myślenia daje ukazanie postaw ludzi bardzo młodych, uczniów, nawet dzieci. Wadą jest tu znowu brak spojrzenia szerszego, tzn. odniesienia spostrzeżeń do wszystkich warstw społecznych. Głównie mowa tu o rodzinach inteligenckich. Jednak poziom intelektualny i duchowy tej młodzieży stwarza tak wielki kontrast ze stanem dzisiejszym, iż w odbiorze Dziennik może natknąć się na pewne niedowierzanie w tej materii.

W Dzienniku jest wiele poezji powstałej w podziemiu, często wszakże są to wiersze pisane w rodzinie autora, także przez jego dzieci. Trudno oceniać walor poetycki tych utworów, ale ich wymowa patriotyczna, duchowa jest niezaprzeczalna. Bez wątpienia wiele z tych wierszy powinno znaleźć miejsce $w$ antologiach poezji lat okupacji, gdyż oddają one panujący wówczas nastrój i wartości duchowe, znajdujące odbicie w tej twórczości. Sporo tej poezji sięga po treści historyczne, przypominając chlubne karty historii polskiej, w tym zmagań z zaborcami. Każdy, kto ma jakieś doświadczenia z czasów okupacji, odnajdzie tu z łatwością odtrutkę na zwątpienie i brak perspektyw w tym trudnym dla Polaków czasie. 
Dziennik stanowi bez wątpienia ważne źródło historyczne, choć może nie dla każdej problematyki okupacyjnej w równej mierze istotne. $Z$ pewnością wszakże dostarcza informacji w kwestiach mniej lub w ogóle nieporuszanych w innych materiałach z tamtych czasów. Każdego miesiąca sporządzany i odnotowywany był budżet domowy. Daje to wgląd w egzystencję okupacyjną przeciętnej rodziny. Również bardzo skrupulatnie zrelacjonowany cennik wielu towarów uzmysławia warunki egzystencji okupacyjnej. Dla historyka czasów okupacyjnych w Generalnym Gubernatorstwie niezmiernie istotna jest fluktuacja cen i podaży oraz popytu w całym okresie okupacyjnym. W Dzienniku znajdujemy na ten temat ścisłe informacje, nawet gdy chodzi o ceny czarnorynkowe.

Ciekawe spostrzeżenie pozornie obniżające wartość poznawczą Dziennika odnosi się do tematyki objętej zainteresowaniem piszących. Łatwo bowiem zauważyć, że szczegółowe zapiski dotyczą przeważnie tylko pewnych rejonów miasta: ulic Niecałej, Radziwiłłowskiej, Staszica, a więc śródmieścia, gdzie w czasie okupacji zamieszkiwała rodzina autora. To wyjasnia w pewnym sensie brak obszerniejszych informacji o losach Żydów lubelskich, o Zamku i Majdanku. Nieliczne wiadomości na te tematy gubią się niejako w natłoku zapisków relacjonujących zdarzenia błahe dnia powszedniego. Oczywiście mogły być także inne przyczyny pomijania tamtych wydarzeń, ale przy tak drobiazgowym relacjonowaniu innych, zgoła nieważnych, ta luka jest zastanawiająca. Warto też zauważyć na marginesie tych spostrzeżeń, że piszących Dziennik absorbowały jednak najbardziej ich przeżycia w łonie rodziny i najbliższego otoczenia. Odnosi się też wrażenie, jak gdyby rzeczywistość okupacyjna i wojenna w pewnym sensie spowszedniała i ważne było tylko przetrwanie.

Z kolei niezwykle ciekawe są relacje dzieci ze szkoły. W przeciwieństwie do terenów polskich włączonych do Rzeszy to była szkoła polskojęzyczna. Nie dowiadujemy się wiele na temat samego programu i nauczania w ogóle, ale znowu jest to raczej oddanie funkcjonowania szkoły, tak jak to postrzega uczeń, zatem niekoniecznie od strony istotnych zagadnień programu i nauczania. Z kolei Dziennik zawiera wiele treści wskazujących na to, iż w domu była edukacja $\mathrm{w}$ zakresie przedmiotów przez okupanta niedozwolonych, zwłaszcza historii.

Mniej wartościowe są zapiski dotyczące rozgrywających się wydarzeń wojennych. Wyraźnie widać tu zależność od prasy gadzinowej względnie niemieckiej, przy czym autor zapisków nie starał się nawet weryfikować ich zawartości propagandowej. Z podawanych informacji wynika też, że w pewnych okresach okupacji nawet te wieści dochodziły do niego nieregularnie. Można suponować nielegalne korzystanie z radioodbiorników i z prasy podziemnej. Jednak nawet systematyczne korzystanie z tych źródeł nie przyczyniłoby się do sporządzenia kompetentnego obrazu wydarzeń wojennych. Przede wszystkim, o czym już wspomniano wyżej, odsianie treści propagandowych od istotnych wiadomości czerpanych z prasy niemieckiej lub gadzinowej przekraczało możliwości nawet tak zorientowanego autora, jak Remigiusz Moszyński.

Wertując pokaźny tom Dziennika, czytelnik mimo woli zadaje sobie pytanie, na czym właściwie zasadza się jego wartość poznawcza. Jest ona niebagatelna, przy tym bardzo zróżnicowana. Jednak choć ze względu na autorów i miejsca, z którego czerpali wiedzę o życiu okupacyjnym, należałoby widzieć w tym dziele poważną pozycję pośród lublinianów, to jednak właśnie w tym punkcie rodzą się uzasadnione wątpliwości. Dziennik wydaje się przede wszystkim bardzo plastyczną historią obejmującą życie pod okupacją w całym Generalnym Gubernatorstwie, a ściśle mówiąc - w większych miastach. Na wsi bowiem kształtowało się ono inaczej. Lublin w narracji jest raczej tłem i punktem odniesienia dla wielu sytuacji okupacyjnego życia. W dodatku Dziennik relacjonuje bytowanie środowiska inteligenckiego, jedynie marginesowo wzmiankując to, co dotyczy innych warstw społeczeństwa. Spojrzenie na życie okupacyjne jest też w dużej mierze widziane przez pryzmat problemów i poglądów tej właśnie warstwy. 
W sumie zatem, zalecając Dziennik jako arcyciekawą lekturę, należy zarazem ostrzec przed kształtowaniem na jego podstawie wyobrażeń o życiu okupacyjnym całego społeczeństwa polskiego, nawet gdyby je ograniczyć do GG. Czerpać można z niego wiedzę na temat atmosfery okupacyjnej, choć też z pewnymi zastrzeżeniami. Na koniec trzeba zaznaczyć, iż utwór tutaj omawiany jest ciekawym pomnikiem literackim. Z konieczności na wielu miejscach lapidarny, stanowi wszakże przekaz ujęty w dobrej i komunikatywnej polszczyźnie.

Na koniec wypada jeszcze zwrócić uwagę na osoby, dzięki którym Dziennik ujrzał światło dzienne. Na pierwszym miejscu wymienić należy panią Barbarę Jaroszową, najmłodszą z czwórki autorów tego dzieła. Jej zasługą jest nie tylko sporo treści Dziennika, ale także wydobycie jego rękopisu z zapomnienia i przygotowanie maszynopisu. Można się domyślać, jak wielkiego wysiłku to wymagało. Jej dziełem jest też pierwsza merytoryczna redakcja tekstu.

Sama publikacja Dziennika nastąpiła z inicjatywy ks. profesora Edwarda Walewandera. On też wziął na siebie trud opracowania tekstu, opatrzenia go obszernym i treściowo pojemnym wstępem, a przede wszystkim odnośnikami objaśniającymi nie zawsze dla współczesnego czytelnika zrozumiałe fragmenty dzieła. Można śmiało rzec, że bez tych objaśnień i dopowiedzeń wiele informacji zawartych we wspomnieniach Remigiusza Moszyńskiego nie dotarłoby do wszystkich czytelników, zwłaszcza do młodszej generacji. A trzeba przyznać, że ich rola wychowawcza jest nie do przecenienia.

Jak w każdym tak osobistym dziele dużą rolę odgrywają ilustracje. Po prostu widzi się ludzi, którzy Dziennik napisali, i często też tych, o których w nim mowa. Tych ilustracji jest w książce kilkadziesiąt.

Dobrze byłoby także, gdyby sporządzono indeks osobowy. Wprawdzie w dziele nie dostrzega się ciżby występujących osób, ale tak potężny tom liczący bez mała 600 stron takiego dopełniania by wymagat. 